\title{
Türkiye İşveren Sendikaları Konfederasyonu'nun Kuruluş Yıllarında Grev Hakkına Yaklaşımı
}

\author{
Nuray EKREM ${ }^{1}$ \\ ORCID: 0000-0002-2700-1906 \\ DOI: $10.54752 /$ ct.1060821
}

\begin{abstract}
Öz: Çalışma 1961-1963 döneminde kademeli olarak kuruluşunu
\end{abstract} tamamlayan TİSK'in bu yıllarda grev hakkına yaklaşımını belirleme amacındadır. Bu yıllar "işveren sendikacılığı" bakımından, hızlı bir yeniden yapilanma ve toparlanma süreci ve yeni bir döneme geçiş aşamasıdır. Söz konusu yıllar, önce Anayasa ve daha sonra 274 ve 275 sayılı yasalarla sendika, toplu iş sözleşmesi ve grev hakkının güvence altına alınması itibariyle çalışma ilişkileri bakımından da yepyeni bir döneme geçişi temsil eden yıllardır. Çalışmada TİSK'in kuruluş yılları ve grev hakkının güvence altına alınma ve kurumsallaşma süreci birbiriyle ilişkili bir biçimde incelenecek, TİSK'in grev hakkının kurumsallaşmasına dair görüşleri Konfederasyon yayınları, basın açıklamaları ve çeşitli kaynaklar üzerinden değerlendirilecektir. Daha sonra dönemin önemli işçi eylemlerinden olan Kavel grevi örneği üzerinden TISK'in fili grev hareketine ilişkin tutum ve davranışları belirlenecektir. Böylece "işveren sendikacıllğının" önemli bir aktörü olan TİSK'in kuruluş yıllarında grev hakkına yaklaşımı, söylem ve uygulamada iki yönlü olarak ortaya konmaya çalışılacaktır.

Anahtar Kelimeler: İşveren Örgütleri, Türkiye İşveren Sendikaları Konfederasyonu, Grev Hakk1, Kavel Grevi

Turkish Confederation of Employer Associations' Approach to the Right to Strike During Its Foundation Years

Abstract: The study aims to determine TISK's approach to the right to strike in the years when TISK has completed its establishment gradually period of 1961-1963. These years were a rapid restructuring and recovery process and a new phase of transition for employers' association. Also in these years, trade union, collective bargaining agreement and right to strike were guaranteed first by the constitution

${ }^{1}$ Doktora Öğrencisi, Kocaeli Üniversitesi, Sosyal Bilimler Enstitüsü, Çalışma Ekonomisi ve Endüstri İlişkileri Ana Bilim Dalı, Sosyal Politika Programı, Makale Geliş Tarihi:30.06.2021 Makale Kabul Tarihi: 12.12.2021 
and then the laws numbered 274 and 275 . In this context, these years additionally mean a transition to a new period in terms of labour relations. In the study, the founded years of TISK and the process of quarantining and institutionalizing the right to strike will be examined in a related manner. TISK's views about the institutionalization of the right to strike will be evaluated through confederation publications, press releases and various sources. Then TISK's attitudes and behaviours regarding the actual strike action will be determined through the example of the Kavel strike which was the important labour movement in that years. In this way the approach of TiSK, which is the most important actor of employers' association, to the right to strike during its foundation years will be tried to be revealed in two ways in discourse and practice.

Key words: Employer Association, Turkish Confederation of Employer Associations, Right to Strike, Kavel Strike

\section{Giriş}

Çalışma TİSK'in kuruluş yıllarında grev hakkına yaklaşımını ortaya koyma amacındadır. TİSK'in kuruluş yılları olarak incelenen dönem, İstanbul İşveren Sendikaları Birliği’nin kurulması ve bu Birliğin ana tüzük değişikliği ile Konfederasyon düzeyine dönüşmesini içeren 1960-1963 y1lları arasını kapsamaktadır. Nitekim TİSK, 1961 Anayasa'sının kabulünden yaklaşık üç ay sonra, 15 Ekim 1961 tarihinde altı "işveren sendikası"2 tarafından oluşturulan

${ }^{2}$ Koray ve Çelik (2007: 285), Türkiye'de “işveren sendikaları” olarak adlandırılan işveren örgütlerinin çalışma ilişkileri yazını açısından oldukça tartışmalı bir kavram olduğuna ve bu kavramın Türkiye’ye özgü olduğuna dikkat çekmektedirler. Nitekim "sendika” kavramı doğrudan işçilerin oluşturduğu örgütler için kullanılmaktadır. Bu bakımdan Anglo-Sakson dünyasında işçi sendikaları için "Trade Union", işveren sendikaları için ise "Employer Association" terimleri kullanılmaktadır. Alman hukuku da işçi, işveren ayrımı yaparak sendikalar için "Gewerkschaft", işveren örgütleri için ise "Arbeitgebervereine" terimlerini kullanmıştır. Koray ve Çelik, bu ayrımın Uluslararası Çalışma Örgütü (ILO) tarafından da kullanıldığını belirtmektedir. ILO İngilizcede işçi sendikaları için "trade union" işveren örgütleri için de "employer organizations" ve Fransızcada işçi sendikaları için "syndicats" işveren örgütleri için ise "organisations d'employeurs" kavramlarını kullanmaktadır. Bunun yanında TISK de İngilizcede "Turkish Confederation of Employer Associations" (Türkiye İşveren Birlikleri Konfederasyonu) adını tercih etmektedir. Ancak bu çalışmada "işveren sendikaları" kavramı kullanılmaktadır. Bunun nedeni Türkiye'de yasal tanımın bu olmasının yanında "işveren örgütleri”" kavramının işveren sendikaları ile birlikte oda, dernek, vakıf gibi diğer işveren örgütlerini de içinde barındırması ve çalışmada sadece "işveren sendikası" statüsündeki TíSK’in değerlendiriliyor oluşudur. 
tüzüğün ardından, 11 Aralık 1961'de gerçekleştirilen genel kurul toplantısıyla kuruluşu hukuken gerçekleşen İstanbul İşveren Sendikaları Birliği'nin devamı niteliğindedir. ${ }^{3}$ İstanbul İssveren Sendikaları Birliği'nin, daha kuruluşundan itibaren belirlediği amaçlar ile yalnızca belirli bir işkolundaki ya da belirli bir bölgedeki işverenlerin değil, tüm işverenlerin sendikal örgütlenmesini sağlayarak, örgütlenmeden doğan gücün imkânlarını kullanmak isteğinde olduğu görülmektedir (İşveren, Kasım 1962: 14). Bu durum Birliğin kuruluş sürecinde aktif olarak yer alan ve işveren sendikacıllğının zayıflığından şikâyet eden kimi örgütler için de geçerlidir. ${ }^{4} \mathrm{Bu}$ bakımdan işveren camiası kendilerini temsil edecek ulusal düzeyde bir kuruluşun oluşması için çalışmalar başlatmıştır. Çalışmalar sonucunda öncelikle, Birlik üyesi işveren sendikalarının hukuki statüleri değiştirilerek yerel düzeydeki sendikalar ulusal düzeye dönüştürülmeye başlanmış ve 1962 yllı içerisinde Birlik üyesi ișveren sendikalarının her biri ulusal düzeyde örgütlü sendikalara dönüşmüştür (Koç, 1980: 33). Böylece ulusal düzeyde örgütlü sendikaların meydana getirdiği bir kuruluş halini almış olan İstanbul İşveren Sendikaları Birliği daha sonra, 20 Aralık 1962'de yapılan 2. Genel Kurul toplantısında kabul edilen ana tüzük değişikliği ile TİSK'e dönüşmüştür.

Bununla birlikte TİSK'in kuruluşunun gerçekleștiği 1960-1963 döneminin, Türkiye'de işveren sendikacıllğının gelişimi bakımından hayli önemli olduğuna ayrıca dikkat çekmek gerekmektedir. İşveren sendikacıllğı 1960-1963 arası dönemde, kendinden önceki ve sonraki dönemlerden farklilıklar içermektedir. 1960 öncesinde bir "tabela sendikacilı̆̆ı" söz konusu iken 1960-1963 arasında hızlı bir toparlanma ve hazırlık süreci sonucunda işveren sendikaları 1963 sonrasında "tam anlamıyla varlık kazanabilmişlerdir" (Esin, 1974: 272). 5 Öte yandan işveren

${ }^{3}$ Birliğin kurucuları, ișveren sendikacılığının birinci döneminde kurulmuş olan Madeni Eşya Sanayicileri Sendikası (1959) ve ara dönemde kuruluşunu tamamlamıs olan İstanbul Tahta Sanayi İşverenleri Sendikası (1961), İstanbul Tekstil Sanayi İşverenleri Sendikası (1961), İstanbul Matbaacılık Kâğıt ve Mukavva İmalatçıları İşverenleri Sendikası (1961), İstanbul Gıda Sanayi İşverenleri Sendikası (1961), İstanbul Cam Sanayi İşverenleri Sendikası'dır (1961) (İşveren, Kasım 1962: 14).

${ }^{4}$ bkz. (MESS, 1999: 53-54).

5 Türkiye'de işveren sendikacıllŭı̆nın gelişimi genel olarak iki ayrı evre üzerinden incelenmektedir. Örneğin Esin (1974: 170), işveren sendikacıllğında birinci evre olarak 1947 tarihli 5018 sayılı İşçi ve İşveren Sendikaları ve Sendika Birlikleri Hakkında Kanun'un kabulünden 1961 Anayasası'na kadar olan dönemi ve ikinci evre olarak ise 1961 Anayasa'sının kabulünden sonrasını ele almaktadır. Bu tür bir ayrıma gitmesinin temel nedeni olarak Esin, ilk devrenin sosyoekonomik koşullarla desteklenmeyen bir yasal düzenleme devri olması, ikinci devrenin ise çoğulcu bir toplum yapısının koşullarına aykırı düşmeyecek yasal düzenlemelere gidilmesi ve birinci evreden farklı olarak ikinci evrede "gerçek" işveren sendikacılığının gelişmesi olarak öne sürmektedir. İşveren sendikacılığının gelişim seyrini inceleyen İlhan Lök de (1966), Esin’in ayrımı ile paralel bir dönemleştirmeyi 
sendikalarının 1960 öncesinde etkinlik gösterememesinin sebebi, Türkiye'de işverenlerin sosyal bir sınıf olarak, bu sınıfın ideolojik bilincini kavrayamamasından kaynaklanmamaktadır. Daha sonra ele alınacağı gibi TİSK daha kuruluş yıllarında son derece güçlü bir sınıf bilincine sahiptir. İşveren sendikacıllı̆ı̆ının asıl gelişiminin 1960 sonrasında gerçekleşmesinin temel nedenleri ise bizzat TISK yöneticileri tarafindan oldukça açıklayıcı bir biçimde ortaya konmaktadır. Örneğin TİSK eski Genel Sekreterlerinden Rafet İbrahimoğlu'na göre (1974:116), 1960 öncesinde işverenlerin sendikal örgütlere ilgi göstermemesinin temel nedenlerinden biri, "işverenlerin, koalisyon yasaklarının bulunduğu dönemlerde dahi sayılarının mahdut olması sebebiyle aralarında görüşme ve haberleşme imkânını her zaman bulabilmiş" olmalarıdır. İbrahimoğlu'na göre "işverenlerin bir araya gelmelerini sağlayan bu durum sürekli kuruluşlar oluşturmayı da geciktirmiştir", ayrıca "işs hayat1, hükümetlerle münasebete, mevzuata ve diğer meselelere ait birçok hususlar, iş adamlarının kendi aralarında devamlı bir temas kurmasını" gerektirdiği için işveren sendikacilığına yönelik yasal düzenleme olmadığı dönemlerde de işveren sendikalar1, "hukuken ve kanunen mevcut olmasalar bile, fillen mevcut olagelmişlerdir". İbrahimoğlu'nun dikkat çektiği diğer bir husus işverenlerin, "sınai, ticari ve ekonomik problemlerini halletmek için çeşitli meslek kuruluşları" meydana getirme imkanına 1960 öncesinde de sahip olmaları nedeniyle "sendikal kuruluşlara iltifatın” az olduğu hususudur. Dolayısıyla İbrahimoğlu'na göre 1960 öncesinde işverenlerin sendikal örgütlenme eğilimlerinin düşüklüğü, hâlihazırda var olan

benzer nedenlerle kullanmaktadır. İşveren sendikalarının doğuşu ve gelişimini incelediği makalesinde R. İbrahimoğlu (1974) ise Esin ve Lök'ten farklı olarak ilk evrenin bitip ikinci evrenin başladığı tarihi 1961 Anayasa'sının kabulü olarak değil, TíSK'in kurulduğu 1962 yılı olarak ele almaktadır. Bu dönemleştirme Türkiye'de işveren sendikacılığının gelişimi konusunda genel durumu yansitmakla birlikte 1960-1963 arası özel dönemi ihmal etmektedir. Diğer taraftan MESS (1999) 1960-1963 aras1 dönemin özelliğini göz önünde bulundurarak Türkiye'de işveren sendikacılı̆̆ının gelişim tarihinin ilk evresini 5018 sayılı kanun ile başlatmakta ancak 27 Mayıs 1960 askeri müdahalesi ile sonlandırmaktadır. Nitekim MESS'e göre 27 Mayıs 1960 askeri müdahalesi ile başlayan 1961 Anayasa'sının kabulü ile devam eden ve Temmuz 1963'de 274 sayll Sendikalar Kanunu ve 275 sayılı Toplu İş Sözleşmesi Grev ve Lokavt Kanunu'nun kabulü ile son bulan dönem, işveren sendikacılığı açısından bir bakıma "1963 sonrasına hazırlık dönemi” niteliği taşıyan ikinci dönemden önceki bir ara dönemdir. Dolayısıyla 1960-1963 arası işveren sendikacılığ1 açısından 1963 sonrasına bir geçiş dönemi olarak değerlendirmek gerekmektedir. Bu bakımdan çalışmada esas alınan ayrım MESS'in dönemleştirmesine benzer biçimde, 19471960 kapsayan birinci dönem, 1960-1963 arasını kapsayan ve bir "ara dönem” olarak nitelenebilecek ikinci dönem ve 1963 sonrasını temsil eden üçüncü dönemdir. Bu dönemleştirmenin işveren sendikacılığının gelişim seyrini ortaya koyması bakımından daha elverişli olduğu düşünülmektedir. 
kanallar nedeniyle işveren sendikalarına ihtiyaç duyulmamasından kaynaklanmaktadır. İbrahimoğlu'na ek olarak, 1989 yılından itibaren uzun bir süre TİSK başkanlığını yürüten Refik Baydur da (2008: 28), Türkiye'de işveren sendikalarının 1960'lı yıllara kadar etkin olamayışının nedenleri arasında işverenlerin "farklı kuruluşlar aracilı̆̆yla temsil edilmesini” belirtmektedir. Baydur'a göre (2008: 57) ayrıca, 1960'lı yıllardan önce işverenlerin sendikalaşma eğilimlerinin zayıf olmasının diğer bir nedeni "işşi sendikalarmm isverenleri tehdit edecek bir örgütlïlïk düzeyine ulaşamamasıdir". Ancak 1961 Anayasa'nın sağladığ1 işçi hakları ve işçi sınıfının 1960'ların henüz ilk yıllarındaki etkili kitlesel eylem ve direnişleri bu durumu değiştirmiştir. İstanbul İşveren Sendikaları Birliği Genel Sekreter Yardımcısı İlhan Lök'ün belirttiği gibi 1961 Anayasası'nın kabul edilmesiyle artık "Münferit işverenin karşısında müessir müeyyidelerle mücehhez bir teşkilât vardır. Daha doğrusu eskiden de var olan teșkilât, toplu müzakereye icbar ve grev müeyyideleri ile teçhiz edilmiştir. İşçilerin, müşterek hareketi bir mana ve ruh, bir müessiriyet kazanmış olmaktadır ve böyle mücehhez bir teşkilâtın karşısına işverenin tek başına çıkması ne kendi menfaatine, ne de memleket menfaatinedir" (Lök, 1966: 240).

Bu bağlamda 1961 Anayasası kabul edildikten sonra işçi sendikalarına koşut olarak çeşitli işkollarında ve İstanbul ile sınırlı olmak üzere, işveren sendikaları kurulmaya başlanmıștır. ${ }^{6}$ TİSK'in kurulușu da bu dönemde gerçekleșmiștir. Bu bakımdan çalışmada TİSK'in kuruluş yılları ve grev hakkının kurumsallaşma süreci ilişkili bir biçimde incelenmiştir. TİSK'in grev hakkına yaklaşımı incelenirken ise Konfederasyon yayınları ve yöneticilerinin açılamaları esas alınmıştır. TİSK'in kuruluş yıllarında yayın organı, düzenli olarak çıkardığ Dergi'de Konfederasyon yöneticilerinin çeşitli konulara dair değerlendirmelerine imzalı bir biçimde yer verilirken, aynı zamanda TISK'in toplantılarına ait tutanaklar ve raporlar, basın açıklamaları v.b. yayınlanmaktadır. Bu bakımdan İşveren Dergisi'nde yer alan verilerin TİSK'in kuruluş yıllarında grev hakkına yaklaşımını ortaya koyabilecek nitelikte olduğu düşünülmektedir. Konfederasyon yöneticilerinin açıklamalarında bireysel değerlendirmelerin yer alma olasılığ1

\footnotetext{
61961 y1lı içinde İstanbul Kimyevi ve Tıbbi Müstahzarat İşverenleri Sendikası, gene aynı yıl içinde İstanbul Matbaacılık Sanayi İşverenleri Sendikası, İstanbul Maden Ocakları ve Torak Sanayi İşverenleri Sendikası, İstanbul Cam Sanayi İşverenleri Sendikası, İstanbul Kara, Deniz, Hava Motorlu Taşıt Vasıtaları İşletme, Montaj ve Yedek Parça İmal Sanayi İşverenleri Sendikası, İstanbul Gıda Sanayi İşverenleri Sendikası gibi sendikalar kurulmuştur (Esin, 1974: 178). Söz konusu işveren sendikaları dışında, Koray ve Topçuoğlu'nun (1994: 74) aktardığı verilere göre, 1961 yılında 35 işveren sendikası ve 1.706 üye, 1962 yllında 47 işveren sendikası ve 1.820 üye ve 1963 yllında ise toplam 1.605 üye sayısına sahip 78 işveren sendikası mevcuttur. Yücekök'ün (1972: 150) verilerine göre ise 1961'de 31, 1962'de 36, 1963 'de 61 işveren sendikası mevcuttur.
} 
düşünülerek, bu açıklamalar TİSK'in örgütsel açıklamaları ile karşılaştırılmıştır. Ayrıca çalışmada elde edilen sonuçların TISSK'in bütün bir tarihi için geçerli olduğu düşünülmemelidir. Nitekim çalışma sadece TíSK'in kuruluş yıllarına odaklanmaktadır. Son olarak TISSK'in grev hakkına yaklaşımını belirleme amacında olan çalışma, amacı bakımından ancak TíSK'in kaynaklarına, görüş ve uygulamalarına yer ayırabilmiş, söz konusu dönemde emek örgütlerinin grev hakkına ve TİSK'in tutumlarına yaklaşımı değerlendirme dışında bırakılmıştır.

\section{TiSK'in Kuruluş Yıllarında Çalışma lilişkilerine Yaklaşımı}

TISS'in kuruluşunun gerçekleştiği dönem, Türkiye çalşma ilişkileri tarihinin önemli dönüm noktalarından birini teşkil etmektedir. "Kurumsallaşmanın temel öğeleri olan sendikal örgütlenme, toplu pazarlık ve grev; sosyal ve iktisadi haklar kapsamında, 1961 Anayasası içinde yer bulmuştur. Bu düzenlemeler, Türkiye çalışma hayatında, önemli ve kendinden öncekilerden farklı yeni bir dönemin başlangıcını oluşturmuştur" (Makal, 2002: 32). "Bu düzenlemelere koşut olarak çıarılan 1963 tarihli iki yasa; 274 sayılı Sendikalar Kanunu ile 275 sayılı Toplu İş Sözleşmesi, Grev ve Lokavt Kanunu da 1983 yılına kadar Türkiye çalışma hayatının temel hukuksal belirleyicileri olmuştur. 1961 Anayasası ve onun temel ilkeleri doğrultusunda yürürlüğe konan çalışma yasaları ile çalışma ilişkilerinin temel kurumları olan sendika, toplu pazarlık, grev-lokavt, ilk defa bir arada ve karş1lıklı ilişkileri içerisinde düzenlemeye kavuşturulmuştur” (Makal, 2002: 32). Bu çerçevede 1960 ’lı yılların çalışma ilişkileri rejimi, erken Cumhuriyet döneminden köklü bir kopuş anlamına gelmektedir. Nitekim 1960'lı yılları, erken Cumhuriyet döneminin paternalist emek rejiminden sinırlı bir neo-korporatizme geçiş olarak değerlendirmek mümkündür (Çelik, 2021: 634). ${ }^{7}$ Ancak 1960’lı y1llarla birlikte, “en azından niyet

\footnotetext{
${ }^{7}$ Her ne kadar 1946 Cemiyetler Kanunu değişikliği ve 1947 Sendikalar Kanunu (5018) ile sendika özgürlüğü rejimine geçilmiş olsa da grevi yasaklayan ve toplu pazarlık hakkının fiilen kullanılmadığı bu rejim, otoriter ve vesayetçi sendikacılıkla maluldür. 1947 rejiminde işçi sendikaları sınıf çıkarlarının temsilcisi ve emek-sermaye-devlet ilişkilerinde eşit bir güç ve taraf değil, işçiler arasında yardımlaşmaya yarayan milli, milliyetçi ve mesleki teşekküller olarak görülmektedir. 1961 Anayasası ile grev ve toplu pazarlık hakkının anayasal güvence altına alınmasıyla işçi sendikaları muavenete muhtaç teşekküller olmaktan çıkıp, devlet ve sermaye ile müzakere edebilecek örgütler haline gelmişlerdir (Çelik, 2021: 634). Bilindiği gibi, 1950’li yıllardan itibaren işçi ve işveren örgütlerinin güçlendiği ve devlet açısından işbirliğine gidilmesi gereken sosyal taraflar konumuna geldiği ülkeleri tanımlamak için, "korporatizm" kavramından farklı olarak "neo-korporatizm" kullanılmaya başlanmıştır (Koray, 2005: 157). Bu bakımdan Türkiye'de de, dünya konjonktürünün genel atmosferine uygun bir biçimde, 1960'lı y1llar ile birlikte neo-korporatist eğilimlerin görüldüğü söylenebilir. Bu eğilimin örnekleri için bkz. (Çelik, 2010: 319-322), (Koray ve Çelik, 2007:
} 
olarak işçi ve işveren kuruluşlarının sosyal taraflar olarak kabul edilmesi”, "sosyal ortaklık" veya "birlikte yönetim" esasina dayanan neo-korporatist uygulamalara yer verilmesi (Koray ve Çelik, 2007: 219-222), aynı dönemde Türkiye'de işçi sendikacıllğı hareketinin siyasallaşmasını olumsuz etkileyen faktörlerin olmadığ1 anlamina gelmemektedir. Nitekim 1960'lar boyunca "anti-komünizm ve milliyetçilik dalgasının devam etmesi sınıf siyasetini güçleştiren bir rol oynamıştır" (Çelik, 2010: 339).

Öte yandan dönemin bu niteliklerini TİSK'in çalışma ilişkilerine yaklaşımında da görmek mümkündür. Çalışmanın devamında inceleneceği gibi TISK, kuruluş yıllarında bir yandan neo-korporatizmi çağrıştıran söylem geliştirirken diğer yandan sendikal hakların "kızıl yangınlara" alet edilmemesi için mücadele yürütmektedir. Buna göre TISSK kuruluş yıllarında, "emek piyasasının iki tarafını teșkil eden ișçi ve işveren topluluklarının hür ve kuvvetli sendikalar halinde teșkilatlanmalarının lüzum ve faydasına" inandığını ve "ancak bu iki taraf teşekküllerinin denk kuvvetler halinde gelissmeleriyle memleket ekonomisine en yararlı şekilde münasebetler kurabileceklerini benimsediğini" belirtmektedir (Altıntelli, Mart 1963: 4). Bu bakımdan, "ne başlı başına sermayenin hâkimiyetine, ne de emeğin sermaye üzerinde baskısına imkân verecek bir dengesizliği arzu etmediğini" ifade eden TİSK, işveren ve işçi sendikaları arasında "yapıc1 davranışlarla sonsuz fayda" sağlanabileceğini ve "hatalı hareketlerin de aynı ölçüde zararlı" olabileceğini savunmakta ve "işçi-ş̧veren ilişkilerinde her zaman en yapıcı zihniyetle hareket etmeyi bir memleket görevi saymaktadır". TISSK'e göre söz konusu "görevde" işveren ve işçiye düşen vazife, "memleketin yarınını elbirliği ile his ve kaprislerden uzak olarak, akıl ve mantık çerçevesinde yaratmanın çare ve tedbirlerini barışçı yollardan aramaktır. $\mathrm{Bu}$ da beraberce istihsali arttırmakla mümkündür. Bu suretle elde edilecek somun büyüyecek ve bu büyüyen somundan da tarafların alacakları paylar artacaktır" (Altıntelli, Mart 1963: 4-5). TİSK örgütlenme "zorunluluğunu" da işçi-işveren ilişkilerinde "denge ihtiyacı" üzerinden açıklamaktadır. TISSK'e göre, "kanunların, hükümetin, milletin, basının, bazı milletlerarası kuruluşların ve bizzat işverenlerin geniş ölçüde teşvikleri ve her türlü manevi destekleri ile 15 yıldan beri memleket çapında örgütlenen ve yapıcı ve koruyucu sendikacılluğ gerçekleştirme yolunda, her gün biraz daha gelişip güçlenen işçi sendikalarına eşit bir kuvvet olarak işverenlerin de Türkiye çapında örgütlenmelerinin zorunluluğunu artık kaçınılmaz bir gerçek olarak kabul etmek gerekir" (İşveren, Ocak 1963: 14). İşverenlerin örgütlenmesini, "kendileri kadar işçilerin de istediğini ve beklediklerini” ifade eden TISK'e göre bu isteğin temel nedeni işçilerin, "iyi münasebetler ve çalıșma barıșının ancak denk kuvvetler arasında kurulabileceğini çok iyi anlamasıdır" (İşveren, Ocak 1963: 14). TİSK’e

219-222). 
göre "bu kuvvet dengesi ise sayı veya güç üstünlüğü ile değil; düşünce ve davranışta, insan hak ve hürriyetlerine saygıda, sosyal adalete inanışta ve bütün bunları hazırlayan bilgi ve anlayış ölçülerinde eşit ortaklık ile sağlanabilir". Bu bakımdan TISSK, "çalışma şartlarını düzeltmek, refah seviyesini yükseltmek, sosyal haklarını genişletmek amaciyla örgütlenen ve bu amaçları gerçekleştirmek üzere şükranla kaydedilecek bir olgunluk içinde cidden yapıcı metotlarla çalışan işçilerin makul hadlerdeki isteklerini kabul etmeyecek bir işverenin pek güç" bulunabileceğini ileri sürerken, "hedeflerine yapıcı ve barış̧̧ı müzakereler yerine kırıc1, yıkıcı usuller ve faaliyetlerle ulaşmaya çalışacak işçi liderlerinin de artık yok denecek kadar az" olduğunu belirtmektedir (İssveren, Ocak 1963: 14-15). Bu bakımdan TISK'in karşı tarafla "denk bir kuvvet halinde örgütlenme zorunluluğu" "bir dövüşe hazırlanma zorunluluğundan değil, yapıcı işbirliği için eşit kuvvet ve haklara sahip olma ihtiyacından doğmaktadır". Başka bir ifadeyle TíSK'e göre "aslolan devamlı sulh ve selamet için, istisna olan cenge hazır bir kuvvet halinde bulunmak gerekir" (İşveren, Ocak 1963: 15). Bu da ancak "çeşitli işkollarında kurulmuş ve kurulacak işveren sendikalarını her suretle destekleyebilecek, üyelerine bilgi, tecrübe ve dokümanlarıly rehber olacak kuvvetli bir merkezi örgütün”, yani TİSK'in varllğı ile mümkün olabilecektir (İşveren, Ocak 1963: 14).

Görüldüğü gibi, TİSK kuruluş döneminde çalışma ilişkilerinde, sosyal taraflar arasında işbirliğini ve dengeyi gözeten açılamalar yapmaktadır. TİSK'in bu açılamaları, Konfederasyon'un kuruluşunda örnek aldığı modele de uygundur. Nitekim TISK kuruluşunda, neo-korporatist yapılanmanın önemli örneklerinden biri olan İsveç’in işveren örgütünü model almıştır. İstanbul İşveren Sendikaları Birliğinin TİSK'e dönüştüğü 2. Genel Kurul toplantısında Başkan Şahap Kocatopçu8, "Birliğin kuruluşundan itibaren işverenleri ulusal düzeyde temsil edecek bir konfederasyonun yapılandırılması için çabalar harcandığını", bu süreçte özellikle "batı âleminin ileri gelen örgütlerinin" incelendiğini ve sonuçta “Türkiye'de işveren teşkilatını en iyi şekilde benimsetebilecek olan yahut benimsendiği nispette itimat sağlayabilecek olan teşkilatın İsveç'teki işveren teşkilatı" olduğuna yönetim kurulunca karar verildiğini belirtmektedir (İşveren, Ocak 1963: 17). Kocatopçu, "İsveç İşveren Sendikaları Konfederasyonu (SAF) Genel Sekreter Yardımcısı ve Türkiye işveren temsilcileri ile yapılan çalışmalar sonucunda tüzük için bir tasarı metni hazırlandığını ve bu metnin daha sonra tekrar

${ }^{8}$ Kocatopçu Türkiye'de işveren örgütlenmesi açısından oldukça önemli bir isimdir. Hayatı boyunca çeşitli işveren örgütlerinin yönetim kademesinde yer alan Kocatopçu, kimi hükümetlerin kabinesinde de yer almıştır. 1954-1980 arasında Türkiye Şişe Cam Fabrikaları Genel Müdürlüğü yapan Kocatopçu, 1962-1967 arasında TISK Başkanlığ1 ve 1985-86 yıllarında da TÜSİAD başkanlığı yapmıştır. Kocatopçu bunlar dişında, 1961 Kurucu Meclis’te yer almış, 1960-61 yıllarında Sanayi Bakanı görevini yürütmüş, 1980-1983 Ulusu Hükümeti'nde Sanayi ve Ticaret Bakanı olmuştur. 
Birlik yönetim kurulu ve Birliğe üye her bir sendikanın yönetim kurulu tarafindan incelenerek son halini aldığını" ifade etmektedir (İşveren, Ocak 1963: 17). Kocatopçu'nun açıklamasına göre, İstanbul İşveren Sendikaları Birliği'ni TísK'e dönüştürecek olan yeni tüzük hazırlanırken, "İsveç İşveren Sendikaları Konfederasyonu Ana tüzüğü, Türkiye Cemiyetler Kanunu, Sendikalar Kanunu" esas alınmıştır (İşveren, Ocak 1963: 17).

Bu bakımdan TíSK kuruluşunda, doğrudan SAF’1 örnek almış ve kuruluş sürecinde İsveçli işveren sendikacılarından destek almıştır. ${ }^{9}$ Bununla birlikte TISK'in SAF örneğini model olarak almasının, bilinçli bir tercihin ürünü olduğuna ayrıca dikkat çekmek gerekmektedir. Nitekim TİSK'in kuruluşunda, dünya işveren hareketinin örneklerini incelediği ve İsveç modelinde karar kıldığ 1 anlaşılmaktadır. $\mathrm{Bu}$ duruma örnek olarak İstanbul İşveren Sendikaları Birliği’nin 2. Genel Kurulu'nda yapılan konuşmalar gösterilebilir. 2. Genel Kurul'da Kocatopçu'nun yukarıda aktarılan, TİSK'in kuruluşunda "İsveç işveren teşkilatının" örnek alındığını ifade ettiği açıklaması üzerine, o dönemde Konfederasyon denetim kurulu yedek üyesi olan Baydur söz almıştır. Konuşmasında, "Batı âleminde" "sendikacılık yönünden Amerika'nın da söz sahibi" olduğunu belirten Baydur, Türkiye'de TíSK'in "işbirliği yaparak çalışma niyetinde olduğu işçi sendikalarının da zaman zaman İsveç sendikacıllı̆ından ayrıldığını" ileri sürmüş ve ABD örneğine rağmen, İsveç modelinin tercih edilmesinin nedenini sormuştur (İşveren, Ocak 1963: 17-18). ${ }^{10}$ Baydur'un bu sorusunu Kocatopçu cevaplandırmış, Konfederasyon kuruluş çalışmalarında ABD'deki işveren hareketinin de incelendiğini ancak “Amerika'daki yüzde yüz liberal ekonominin” Türkiye'deki ekonomik yapiya uygun olmadığını ve bu bakımdan Türkiye'de "iktisadi devlet teşekkülleri ile özel teşebbüsün işveren olarak müşterek bir hudut çizerek çalışmak zaruretinde bulunmasının" ABD sendikacilığına uygun olmadığını ifade etmiştir. Kocatopçu ayrıca ABD'de “işverenlerin organize olamadıklarını" belirtmekte ve kendilerinin "daha organize bir vaziyette çalışan işverenleri" örnek aldıklarını ifade etmektedir (İşveren, Ocak 1963: 17-18). Bu bakımdan TİSK'in kuruluş sürecinde, işveren sendikacılı̆̆ının dünya örneklerinin ve bunların hangi sınıfsal çıarlara karşılık

\footnotetext{
9 İstanbul İşveren Sendikaları Birliği Türkiye'de “Bakanlıklararası Prodüktivite Komitesi Prodüktivite Merkezi'nin, işverenlerin teşkilatlanma yolunda yaptıkları çalışmalarla ilgilendiğini" belirtmektedir. Bu bakımdan "Prodüktivite Merkezi, bu konuda gerekli yardımı temin için OECD'ye başvurmuş" ve OECD ise "İsveç'li sendikacı Lennart Cronqvist'i” 'Türkiye'ye göndermiştir (İşveren, 1962: 14). Böylece Türkiye'ye gelen ve o dönemde SAF'ın genel sekreter yardımcısı olan Cronqvist, Birlik yönetimiyle 10 gün süren bir eğitim çalışması yürütmüş, kendi ülkesinden örnekler vererek tavsiyelerde bulunmuştur. Cronqvist’in yürüttüğü eğitim sürecinin ayrıntıları için bkz. (İşveren, 1962: 14-16).

${ }^{10}$ ABD'de işveren hareketinin temel niteliğinin, "19. yüzyıl boyunca ve 20. yüzyıllın ilk otuz yılında işçi sendikacılı̆̆ına karşı düşmanlık beslemek” olduğu söylenebilir (Esin, 1974: 95).
} 
geldiğini iyi bildiği, bu yönde ulusal girişimlerde bulunduğu ve uluslar arası kurum ve kuruluşlar ile bağlantılarını sürdürdüğü söylenebilir.

Daha önce belirtildiği gibi TİSK'in örnek aldığı SAF modeli, sosyal taraflar arasında işbirliği, uzlaşı ve diyalog yöntemini esas almaktadır. Bu yöntemin Birlik yönetimince bir tür "emniyet tedbiri”" olarak algılandığı ileri sürülebilir. Nitekim Kocatopçu TISK'in kuruluşunda SAF'ın örnek alındığını belirttiği demecinde, 1902 y1lında kurulan SAF'ın yönteminin "aşağı yukar1 60 sene devamlı olarak kullanıldığ1 halde aksamamasını", "işçi-işveren ahenginde sağlam bir delil" olarak değerlendirmektedir. Kocatopçu'ya göre bu örnek Türkiye'de "başlangiç için, daha emekleme devresinde bulunan işveren sendikacillğı bakımından emniyetli bir temel taşı" niteliğiyle "daha az risk" taşımaktadır (İşveren, Ocak 1963: 17-18). Çünkü TISK camiasına göre "işçi-işveren ahenginin" sağlanmasıyla "milli varlığın sermayeci ve emekçi ortakları" "işbirliği ile artan milli gelir ve verim fazlasından hakları olan payı almak için sendikalizmin yıkıcı, ihtilâlci metotlarına itibar etmeyip, demokratik hukuk düzeni içinde adil bir sosyal politika ile gerçekleştirileceğine inandıkları sosyal haklarını, meşru mücadele yollarından kazanmayı tercih edeceklerdir" ve bu durum "geleceğe güvenin en güzel örneğini" temsil etmektedir (Kip, 1962: 11). SAF örneği bu bakımdan 1960'l yılların neo-korporatist ve antikomünist eğilimi ile uyumludur. Bununla birlikte TíSK'in "daha az riskli" bulduğu SAF örneği İsveç'te, uzun bir geçmişe sahip olan ve sosyal ortaklık anlayışını esas alan neo-korporatist yapıya ve uzlaşma geleneğine dayanmakta ve bu gelenek çalışma ilişkilerinde sosyal tarafları devreye sokan ve birlikte yönetim olarak anlam kazanan çok boyutlu bir anlayış ve uygulamaları gerektirmektedir (Koray ve Çelik, 2007: 219). ${ }^{11}$ Dolayısıyla TISK'in tüzüğünde SAF'ın tüzügüne benzer düzenlemelere yer vermesi ve bu yönde söylem geliştirmesi tek başına "sosyal ortaklık” anlayışının kurulduğunu göstermemektedir. Nitekim çalışmanın devamında görüleceği gibi TİSK kuruluşundan hemen sonra, bu söylemlerine rağmen, ödenmeyen ikramiyelerin ödenmesi ve sendikaya üye olmaları nedeniyle işten çıkarılan işçilerin işe geri alınması talebiyle grev yapan işçileri "milli düşman" konumuna sokmuştur.

\section{TiSK'in Grev Hakkının Kurumsallaşmasına Yaklaşımı}

Grev hakkının güvence altına alındığı 1961 Anayasası'nın düzenlenme sürecinde ne İstanbul İşveren Sendikaları Birliği ne de TİSK vardır. ${ }^{12}$ Bununla birlikte TİSK

\footnotetext{
${ }^{11} 1$ İsveç modelinin ayrıntılı bilgisi için bkz. (Koray ve Çelik, 2007: 116-121).

121961 Anayasası Kurucu Meclis tarafindan hazırlanmıştır. Kurucu Meclis ise MBK ile toplumun çeşitli kesimlerinden meydana gelen Temsilciler Meclisi'nden oluşmuştur. Temsilciler Meclisi'nde siyasi partilerden, barolardan, basından, esnaf kuruluşlarından, üniversitelerden, yarg1 organlarından, sendikalardan, odalardan vb. seçilen temsilciler yer
} 
kurulduktan sonra konuya dair yorumlarında, Anayasa'nın sosyal içeriğini destekleyen açıklamalarda bulunmuştur. TİSK Başkan Vekili Mümtaz Altınelli, "işveren-işçi münasebetlerinde" Konfederasyon politikasının temel ilkelerinden ilkini "sosyal adalet" olarak belirlerken, "Anayasa teminatı altındaki demokratik bir sosyal devlet nizamının gerektirdiği sosyal adalet ilkelerine gönülden bağlı bulunduklarını" ve "bütün davranıșlarıyla bu samimi inanıșın gerçekleștiğini görmek ve göstermek azminde” olduklarını belirtmektedir (Altınelli, Mart 1963: 4).

almaktadır. Yukarıda belirtildiğgi gibi, 1961 Anayasasının hazırlanma sürecinde işveren sendikalarını temsil eden bir üst örgüt henüz kurulmamıștır. Bu dönemde ișverenlerin hükümet nezdinde temsili daha çok odalar üzerinden yürütülmektedir. Temsilciler Meclisi'nde de işverenler, odalardan seçilen isimler aracillğıyla temsil edilmiştir. Temsilciler Meclisi’nde işverenlerin temsil oranı \% 6.98 iken (tüccar-sanayici ve özel sektör yöneticisi toplamı), işçi-sendikacı kökenli üyeler bu oranın yaklaşık üçte biri, \% 2,21'dir (Çoker, Gürsel ve diğerleri, tarihsiz: 2673-2726). Öte yandan Temsilciler Meclisi’nde yer alan işveren temsilcilerinin, Anayasa tasarısı görüşülürken, tasarıda yer alan sendikal hakların düzenlenmesini genel olarak destekledikleri söylenebilir. Örneğin sendika hakkının, "calsanlar ve isverenler, önceden izin almaksızm, sendikalar ve sendika birlikleri kurma, bunlara

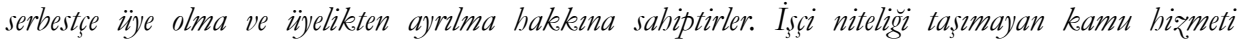
görevlilerinin bu alandaki baklar kanunla düzenlenir. Sendika ve sendika birliklerinin tüzükleri, yönetim ve işleyişleri demokratik esaslara aykır olamą" sseklinde düzenlendiği tasarı metninin 45. maddesi görüşülürken issveren temsilcilerinin bu maddeye dair herhangi bir yorum veya değișiklik talebi sunmadığı, Anayasa Komisyonu'nun hazırladığı taslağı aynen kabul ettikleri görülmektedir. 45. maddenin görüssme tutanakları için bkz. (Temsilciler Meclisi Tutanak Dergisi, 17.04.1961, Cilt: 3, 46. Birleşim). Ancak Temsilciler Meclisi’nde yer alan işveren temsilcilerinin, Anayasa tasarısı görüşülürken, sendika ve toplu sözleşme hakkından farklı olarak grev hakkına ihtiyatlı yaklaştıkları görülmektedir. Nitekim, "toplu sözleşme ve grev hakkının", "işçiler, işverenlerle olan münasebetlerinde, iktisadî ve sosyal durumlarını korumak veya düzeltmek amacıyla toplu sözleşme ve grev haklarına sahiptirler. Grev hakkının kullanılması ve istisnaları kanunla düzenlenir" şeklinde düzenlendiği tasarının 46. maddesi görüşülürken, işveren temsilcileri söz konusu maddenin değiştirilmesi için tekliflerde bulunmuşlardır. $\mathrm{Bu}$ tekliflerde işveren temsilcileri, "grevin bir hak olarak anayasada tanınmasını demokrasinin ve demokrasi anlayışının kaydettiği gelişmenin tabii bir neticesi" olarak algıladıklarını ancak grev hakkının "ahenkli bir sosyal nizam içinde yürümesini temin edecek tedbirlerin alınabileceği” görüşünü savunmaktadır. Bu bakımdan işveren temsilcileri grev hakkının ne zaman kullanılmaya başlanacağına dair "kesinlik" talep etmekte ve grev hakkının yanında lokavtın anayasaya eklenmesini istemektedir. Bununla birlikte işveren temsilcilerinin 46. maddeye ilişkin özellikle üzerinde durduğu lokavtın anayasaya eklenmesi, Temsilciler Meclisi tarafindan kabul edilmemiştir. Nitekim ortak görüsse göre, "Anayasaya konulan, temel haklar arasına giren sosyal haklar, iktisaden zayıf olanları korumak için tanınmış haklardır. Lokavt böyle değildir. Bir insan hakkı şeklinde ayrıca Anayasada belirtilmemesi; gerekirse, kanun koyucu tarafindan kabul edilmesi yolu tercih edilmelidir." 46. maddenin görüş̧me tutanakları için bkz. (Temsilciler Meclisi Tutanak Dergisi, 17.04.1961, Cilt: 3, 46. Birleşim). 
Yine TISKK Genel Sekreteri Haldun Kip, "bir yandan fertlerin hürriyet içinde gelişmelerini sağlayacak insan haklarını teminat altına alırken, diğer yandan, sosyal adalet çerçevesi içinde fert hak ve hürriyetlerini sinırlayıc1 tedbirlerle toplumun üstün menfaatlerini korumaya çalışan, sosyal eğilimli bir politik sistemin" "milletçe kolaylıkla benimsenmiş" olmasını övmektedir. Kip’e göre "başka milletlerin çetin sosyal mücadelelerle geçirdikleri yüzyılları iki üç sıçrayıșta atlayıp muasır Batı demokrasilerinin sosyal hukuk düzeninin" Türkiye'de "sarsintısızca" yerleştirilebilmesi "milletin, toplum şuurunda yerleşmiş olan sosyal adalet geleneğinden" kaynaklanmaktadır (Kip, Ekim 1962: 10). Bu bakımdan kuruluş yıllarında, "hürriyet için kalkınmanın" ilk şartını "sosyal adalet" olarak belirleyen TISK, "sosyal adalet prensibine ve bunu koruyan hükümlerin müeyyidesi olan, grev ve lokavta" işverenlerin "samimiyetle inandıklarını" ve "çalışanlarla çalıştıranlar arasındaki ilișkilerin memleket yararına ahenklendirilmesi" konusunda "devletin hakemlik görevinin öneminin büyük olduğunu” belirtmektedir (Kocatopçu, Kasım 1962: 3-4).

TISK 1961 Anayasası'nın sosyal içeriğinden başka, daha önce belirtildiği gibi, kuruluş yıllarında, "emek piyasasının iki tarafını teşkil eden işçi ve işveren topluluklarının hür ve kuvvetli sendikalar halinde teşkilatlanmalarının" gerekli ve faydalı olacağını savunmakta, işçilerin sendika hakkını desteklemektedir. Sendika hakkı dışında aynı dönemde yani, henüz 275 sayılı Kanun kabul edilmeden önce TISK, "kimi işverenler ile işçi sendikaları arasında imzalanan toplu iş sözleşmelerini" de, her ne kadar işverenleri bu konuda "etraflı düşünmeye" davet etse de, genel olarak desteklemektedir. Nitekim TİSK'e göre imzalanan sözleşmeler "bir iyi niyetin ifadesidir, yasal düzenlemeler beklenmeden de insanlar ilişkilerini pekâlâ belirli kurallara bağlayabilirler". Ancak bu yapilırken yani, "belirli bir süre için tarafları bağlayan ve her bakımdan son derece mühim olan toplu sözleşme gibi akitler imzalanırken, alınan kararları daha etraflı düşünmek elzemdir". Aksi takdirde "iyi niyet ifadesi gibi görülen şeyler sonradan büyük mahzurlar doğurabilir" (İşveren, Ocak 1963a: 22). TİSK bu bakımdan "her şeyden fazla işvereni ve hatta işçi ve sendikayı hareket ve karar verme serbestisinden" alıkoyacak ve toplu iş sözleşmelerinde bulunması arzu edilmeyen hususlardan en önemlilerini "kapalı işyeri”" ve "sendikalı işyeri”" olarak belirlemektedir. ${ }^{13}$ TİSK’e göre "işverenler için bir

13 TİSK'in toplu sözleşmede bulunmasını istemediği "kapalı işyeri”, işe yalnız sendika üyesi olanların alınabilmesidir. Diğer bir ifadeyle kapalı işyeri, işverenin kendi işyerini temsil eden işkolundaki sendikaya üye işçilerden başka hiç kimseyi işe alamaması demektir. TÍSK’in toplu sözleşmede bulunmasını istemediği "sendikalı işyeri”" ise işverenin işe aldığı işçinin, iş sözleşmesinin başlamasıyla birlikte ya da kısa bir süre sonra sendikaya üye olmasıdır, yani işveren bir işçiyi işe alırken, işçiye iş şartlarından biri olarak işçi sendikasına üye kaydedileceğini bildirmesi ve ancak bu şartın işçi tarafından kabul edilmesi halinde işe alınmasidir. 
nevi zorlayıcı çalıştırma şekli olan ve işçi sendikası için de kendi çare ve kaynakları dışında suni bir gelir gruplaşma memba1 havası yaratmak istidadındaki” bu iki husus "sözleşmelerde yer almadan önce gerek işverenler gerekse işçi sendikaları yöneticileri tarafından titizlikle ele alınmalıdır" (İşveren, Ocak 1963a: 22-24).

TİSK 275 sayılı Kanun kabul edilmeden önce, çıkan uyuşmazlıkların da "dostça ve barış yoluyla müzakereler" yapılarak "işbirliğ̣" temelinde yürütülmesi gerektiğini savunmaktadır. Bununla birlikte "karşllklı güven ve dostluk havası", İstanbul İşveren Sendikaları Birliği ile TÜRK-İŞ arasında kısmen sağlanmıştır. Nitekim Birlik, TÜRK-ISS ile yapılan "temaslar" sonucunda "önceleri kendileri hakkında beslendiği sezilen kuşkulu duyguların giderildiğini”" ifade etmektedir (İşveren, Kasım 1962: 22). Ayrıca Birlik ve TÜRK-İŞ arasında bir "anlaşma" sağlanmıştır. Bu anlaşmaya göre, "işverenler ile işçiler ve dolayısıyla işçi sendikaları arasında çıkan her türlü uyuşmazlıklar ilgili idari ve kazaî mercilere aksettirilmeden önce", Birlik ve TÜRK-İŞ’in "hakemliği altında görüşülecek ve sonuca bağlanacaktır". Birlik, TÜRK-İŞ ile sağlanan bu anlaşmanın sonuçlarının da alındığını, örneğin, "Temmuz-Ekim 1962 arasında, İl Hakem Kurulu'na ve İş Mahkemeleri'ne intikal etmiş birçok anlaşmazlığın giderildiğini” belirtmektedir (İşveren, Kasım 1962: 22). Bu bakımdan TISK, işçi sendikaları ile kurulan "dostane münasebetler" ve "bütün ihtilafların aralarında, üst teşekküllerin hakemlik ve rehberliğinde çözüme kavuşturulması gibi güzel örnekler nedeniyle huzur ve inşirah içinde" olduğunu belirtmektedir. TİSK aynı zamanda, "toplu sözleşme devri içinde de -grev ve lokavt müeyyidelerine rağmen- aynı dostluk ve karşlıklı güven havası içinde görüşme, pazarlık ve sözleşme yapılabileceğine inandıklarını" ifade etmekte ve "geleceğe güvenle, elimizi dost ve kardeş işçilerimize uzatmaktan zevk ve bahtiyarlık duyuyoruz" demektedir (Kip, Ekim 1962: 11).

TİSK 274 ve 275 sayılı kanunların hazırlanmasını da, bazı değişiklik önerileri sunmuş olsa da, desteklemiştir. 274 sayılı yasanın tasarısını yorumlarken İstanbul İşveren Sendikaları Birliği, "vaktiyle yaptıkları tenkitlerin tasarıda akis bulduğunu memnuniyetle müşahede" ettiklerini belirtmektedir (Saymen, Aralık 1962: 9-14).14 274 sayılı Kanun dişında TİSK, 275 sayılı Kanun'un tasarısını yorumlarken ise "toplu iş sözleşmesi düzeninin diğer demokratik ülkelerde olduğu gibi Türkiye'de de yer alması zamanın geldiğini”" belirtmektedir (TOBB, 1962: 3).15

14 Birliğe göre tasarının açık bıraktığı bir nokta sendikaların "teftiş ve murakabesi” ile ilgilidir (Saymen, Aralık 1962: 9-14).

15 TISSK, henüz birlik statüsündeyken "Çalışma Bakanlığı tarafından bir sureti” kendilerine gönderilen 275 sayılı Kanun'un tasarı metni hakkında, "görüş ve tenkitlerin hazırlanarak üyelere sunulduğunu” belirtmektedir. TISK'in üyelerine sunduğu bu rapor, daha sonra İstanbul Sanayi Odası (İSO) tarafindan hazırlanan diğer bir raporla, TİSK ve İSO üyelerinden oluşturulan bir karma komisyon tarafindan incelenmesinden ardından birleştirilmiştir. Birleştirilen bu ortak rapor TOBB’da toplanan bir komisyonca görüşülmüş 
Ancak TİSK'in bu tutumu söz konusu grev hakkı olunca değişmektedir. Nitekim TISK, 275 sayılı Kanun'un tasarısını değerlendirirken, grev hakkının uygulamada yaratabileceği “tahribatı" azaltma gayesiyle, grevin tanımından, ceza hükümlerine kadar kapsamlı bir değişiklik öneri listesi sunmaktadır. ${ }^{16}$ Bununla birlikte TİSK'in bu önerilerinin kısmen karşıllk bulduğu söylenebilir. Örneğin, 275 sayll Kanun'da, grev hakkının uygulamasını sınırlayan "grev ertelemesine" yer verilmiş ve ayrıca grev hakkının yanında 1961 Anayasası'nda yer almayan lokavt da, grev hakkıyla eşdeğer bir biçimde düzenlenerek işverenlere bir hak olarak tanınmıştır. ${ }^{17}$ TİSK, 275 sayılı Kanun'un son halinden memnundur. 274 ve 275 sayll kanunların kabul edilmesini işçi ve işverenlerin "bayramı" olarak kutlayan TİSK, "kazanılan bu zaferin", "bir zümrenin diğer zümre aleyhinde galebesi" olmadığını, aksine "gerici zihniyete karşı müşterek bir zafer" olduğunu belirtmektedir (İşveren, Temmuz 1963: 19-20). Ancak yine de TíSK'in söz konusu kanunlarn kabulü ile sağlanan hakların "kötüye kullanılma endişesini”" taşıdığı söylenebilir. Daha önce, Türkiye'de "henüz narin bir filiz halindeki sendikalizmi muzır cereyanlarla beslenen sellerden, hoyrat ellerdeki baltalardan, kızıl yangınların alevlerinden korumanın" işverenler ile işçiler için "kutsal bir borç" olduğunu dile getiren TİSK (Kip, 1962: 11), 274 ve 275

ve sonuçta “Türkiye'deki işverenlerin” 275 sayıll Kanun'a dair “ortak görüşü” tespit edilmiştir. Söz konusu ortak görüş ise TOBB tarafindan "Türkiye işverenlerini temsilen" Çalışma Bakanlığına sunulmuştur (İşveren, Kasım 1962: 17).

${ }^{16}$ Daha önce belirtildiği gibi, 275 sayılı Kanun tasarısına ilişkin işveren örgütlerinin görüşleri birleştirilerek hazırlanan ortak bir raporla TOBB tarafından Çalışma Bakanlı̆̆ı'na sunulmuştur. Bu raporda işveren camiası, henüz tasarı halindeyken grev tanımının içeriğine yeni maddeler ekleyerek, uyuşmazlık sürecinde greve alternatif yöntemler geliştirerek, grev yasaklarının ve ertelemelerinin kapsamını genişleterek, grev sürecinde işçinin temel giderlerini arttıracak ve böylece grevi sürdürme gücünü kıracak önlemler önererek, grevin işverene yükleyebileceği zararların telafi edilmesini sağlayacak fonların oluşturulmasını isteyerek, hakem kurullarında işverenin temsilini güçlendirerek ve grevin cezai yaptırımlarını arttırarak grev hakkını sınırlandırmak istemiştir. Ayrıntılı bilgi için bkz. (TOBB, 1962: 3-35). 17 İş sözleşmesi taraflarının işi yapmamak ve ücret ödememek yoluyla karşı tarafa ekonomik baskıda bulunduğu, grev ve lokavtta biçimsel bir benzerlik var gibi görünmektedir. Grevde işçinin ücret kaybı, lokavtta işverenin üretim kaybı söz konusudur. Ancak bu biçimsel eşitliğin arkasında, gerçekte bir eşitsizlik vardır. Çünkü işçiler greve gitmekle kendilerini yegâne geçim araçları olan ücretlerinden yoksun bırakarak yaşamsal varlıklarını ortaya koymaktadırlar; buna karşılık lokavtta, işverenin sadece kar kaybı söz konusudur. Grevde insanın yaşamının sürmesine ilişkin bir risk, lokavtta bir mal varlığı riski ortaya çıkmaktadır. Grev ile lokavt arasındaki bu nitelik farkı nedeniyle, Batılı ülkelerde genellikle grev vazgeçilmez temel insan hakları arasında yer alırken, lokavt hak olarak tanınmayan, yasal düzenlemeden yoksun, meşruluğu tartışmalı, uygulanması ise dar sınırlar içinde tutulan bir eylem türüdür (Balc1, 1998: 322). Ancak yukarıda belirtildiği gibi, 275 sayılı Kanun grev hakkı ve lokavtın arasındaki nitelik farkını dikkate almadan, bu ikisini bir arada ve taraflar arasında karşılıklı bir hak olarak düzenlemiştir. 
sayll kanunların kabul edilmesinden sonra, bu borcu işçilere yeniden hatırlatmaktadır. TISK işçileri özellikle grev hakkının "kötüye kullanılmaması" konusunda uyarmakta ve işçilerden bu hakkı "temkin ve basiret" ile ele almasını ve grevden ziyade asıl olarak "barışçı yollara" başvurmasını istemektedir. TíSK'e göre "grev ve lokavt hakkı, annelerin çocuklarının ellerine geçmesinden korktukları bir bıçağa benzemektedir. Çocuk artık büyüdüğünü, bıçağını faydalı işlerde kullanacağını, bu bıçakla hem kendi ellerini kesmeyeceğini, hem de karşısındakilere zarar vermeyeceğini ispat edecektir" (İşveren, Temmuz 1963a: 3). TíSK’e göre ayrıca, "barışçı işbirliği ile artacak istihsalin büyüteceği somundan pay alacak tarafların bu isteklerine de barışçı yollardan kavuşabilecekleri; aksi halde büyük huzursuzluklar doğacağı da bir gerçektir. Eğer bir hak var ise muhakkak bunu koruyan bir hukuk nizamı da vardır ve bu düzeni sarsacak şekilde fiili hareketlerden kaçınmak, kanunlara saygilı vatandaş olarak işçi ve işverenlerin; böyle hareketlere yer vermemek de hukuk nizamını korumakla görevli olan devletin, dolayısıyla hükümetin esas vazifesidir" (Altıntelli, Mart 1963: 5).

\section{TiSK'in Grev Hakkının Uygulanmasına Yaklaşımı: Kavel Grevi Örneği}

TISKK kuruluş yıllarında, daha önce de belirtildiği gibi, işçi-işveren ilişkilerinde "yapıcı davranışlarla sonsuz fayda" sağlanabileceğini, "hatalı hareketlerin de aynı ölçüde zararlı" olabileceğini ve bu bakımdan "düzeni sarsacak fiili hareketlerden kaçınmak" gerektiğini savunmaktadır. Yine hatırlanacağ1 üzere, TíSK'in "yapıc1 işbirliği”" görüşü, aynı dönemde TÜRK-İŞ tarafindan da desteklenmiş ve iki taraf arasında "dostane münasebetler" kurulmuştur. Ancak bu durum sözü edilen dönemde "uyuşmazlık" olmadığ1 anlamına gelmemektedir. Tersine bu dönemde işçi eylemlerinde belirgin bir yükseliş yaşanmıştır. ${ }^{18}$ Ancak TISK, bu eylemler ile mücadeleye de hazırdır. Nitekim TISSK "aslolan devamlı sulh ve selamet için, istisna

18 Çelik (2010: 363), 27 Mayıs’tan kısa bir süre sonra işçi eylemlerinde belirgin bir yükseliş ve siyasallaşma yaşandığını ve bu bakımdan kelimenin tam anlamıyla Türkiye işçi sınıfının tarih sahnesine çıktığını ifade etmektedir. Söz konusu eylemler düşük ücretlerden, kötü çalışma koşullarına, grev yasasının çıkartılmasına, kamu işletmelerinin yöneticilerinin despot tavırlarına gösterilen tepkiye kadar geniş bir yelpazeyi kapsamıştır. Dönemin belli başlı işçi hareketleri arasında, 5 bin Sümerbank işçisinin yalınayak yürüyüşü (25 Kasım 1961), Saraçhane Mitingi (31 Aralık 1961), 5 bine yakın işsizin Ulus Meydanı'ndan TBMM'ye yürüyüşü ve polisle çatışması (3 Mayıs 1962), Yapı-İş Sendikası'nın Zonguldak Ereğlisi'ndeki düzenlediği miting ve işten atmalara karşı protestolar (12-13 Ağustos 1962) ve Kavel grevi (Ocak 1963) sayılabilir. Ayrıca Çelik'in Fişek’ten aktardığına göre (2010: 363), 1961-1963 döneminde (274-275 sayılı yasaların düzenlenmesinden önce) 10 grev, 6 oturma grevi, 7 sakal grevi, 12 sessiz yürüyüş, 5 miting ve gösteri gerçekleştirilmiştir. 
olan cenge hazır bir kuvvet halinde" bulunmayı amaç edinmiştir. Bu bakımdan Kavel grevi TíSK'in kuruluş yllarında işçi eylemlerini ve "istisna olan cenk" halinde TİSK'in tutumunu gösteren iyi bir örnektir.

Kavel grevi, 28 Ocak 1963 tarihinde İstanbul, İstinye'deki Vehbi Koç, Eli Burla ve Emin Aktar ortaklarına ait olan ve muhtelif dairelerinde 173 işçi ve 50 büro personelinin çalıștığı Kavel Kablo Fabrikası'nda bașlamıștır. 275 Sayılı Kanun henüz kabul edilmeden evvel TÜRK-IŞ’e bağlı Maden-İş Sendikası'na üye işçilerce başlatılan bu grev, 4 Mart'ta imzalanan protokol ile sonlanmıştır. ${ }^{19}$ Maden-İş̧ Sendikası'nın yayınladığı bildiriye göre, Kavel grevinin temel nedeni yeni atanan Genel Müdür İbrahim Üzümcü'nün kimi uygulamalarıdır. Üzümcü atandıktan sonra "5 yıldan beri işçilere verilen ikramiyeleri kaldırmış" ve bunun dışında "fabrikadaki sendikalı işçileri istifaya zorlamış ve işyeri sendika temsilcisi ile birlikte 4 işçinin işine son vermiştir" (İşveren, Mart 1963: 16-17).20 İşçiler Üzümcü’nün uygulamalarını protesto etmek amacıyla oturma grevine başlamış, ancak daha sonra bu protesto fabrika önünde kurulan çadırlarda devam ederek bir "direnişe” (TSA, 1998: 239) dönüşmüştür. Bu direniş Kavel Fabrikasını aşıp kimi diğer fabrikalar ve kamuoyu tarafindan da desteklenmiştir. ${ }^{21}$

19 Aydın (2010: 151-152), Kavel grevinin 275 sayll Kanun kabul edilmeden uygulanmas1 itibariyle "kanunsuz" bir grev olduğunu belirtmektedir. Ancak Aydın aynı zamanda Kavel grevinin, hem Anayasa'nın grev hakkını tanımış olması, hem de edindiği toplumsal destek sayesinde meșru bir grev olarak kabul gördüğünü vurgulamaktadır. "Kanunsuz" ama meșru bir "hak grevi" olarak Kavel, "gelenek yaratan bir eylem" olarak daha sonraki dönemde işçi mücadelesine esin kaynağı olmuştur.

${ }_{20}$ Maden-İş’in yayınladığı bildiride, ilk olarak “ikramiye” konusundaki değişikliğe şu şekilde vurgu yapılmaktadır; "Kavel Kablo Fabrikasinda çallşan işsiler 5 yuldan beri isyerinde işveren durumunda bulunanlarla tam bir abenk. kurmustu. Fakat gecen yal Kasım ayznda Fabrikaya yeni bir genel müdür atanmıştır. Bu zat tam yetki ile geldiğini ve kendisinden baskea kimsede yetki bulunmadiğm isçilere bildirmis, sonra da 5 yuldan beri iş̧ilere verilmiş olan ikramiyeleri kaldormustır. Sebep olarak da fabrika kârm iki misline çıkarmak taabhüdü ile işbaşına getirildiğini açılamıştır. İsyerindeki kâr iki misline çıkarmake isteyen işveren yulbaş ikeramiyesini kaldırn yeni usuller koymaya başlaynnca, isşiler kanuni baklarmm ellerinden alındiğmn görmüsstür" (İşveren, Mart 1963: 16). Bildiride aynı zamanda Üzümcü'nün “benim olduğum yerde sendikal barnamą” diyerek sendikalı işçileri istifaya zorladığı ve 50 kadar işçinin istifa mektuplarını bizzat yazdırdığı belirtilmektedir. Bildiriye göre Üzümcü "burada benim sözüm geçer" diyerek sendika temsilcilerine karş1 harekete girişmiş ve ilk olarak Maden-İş’in Şişli Bölge Merkez Şubesi Başkanı ve İşyeri Sendika Temsilcisi İlyas Kabil ile 4 arkadaşının işine son vermiştir. Bunun dışında bildiride Üzümcü'nün verdiği sözleri tutmadığ1 ve işçileri tahrik edici sözler sarf ettiği ve bütün bu nedenlerle grevin başladığı belirtilmektedir (İşveren, Mart 1963: 16-17).

${ }^{21}$ Kavel işçilerine destekler için bkz. (Yön, 6 Şubat 1963: 4), (Yön, 13 Şubat 1963: 5). Kamuoyu dışında grevci işçilerle "Kavel önünde bir gece" geçiren bir gazetecinin tanıklı̆̆ına göre, Fabrikanın "emniyetini”" sağlayan polisler de işçilere sempatiyle yaklaşmaktadır. Nitekim gecenin soğuğundan kaçıp, işçilerin yaktığı ateşe sığınan bir polis, 
Kavel grevi diğer işçiler, işçi sendikaları ve kamuoyu tarafindan benimsenirken, grev süresince Kavel işvereninin temsili de oldukça güçlü bir biçimde sağlanmıştır. Nitekim bu süreçte TİSK, bütün imkânlarını işveren için seferber etmiş, ihtilafin giderilmesi yolunda izlenecek bütün yol ve yöntemlere, oluşturulan stratejiye, geliştirilen taktiklere karar veren taraf olmuştur (Aydın, 2010: 69).22 TISSK'in Kavel grevine hayli etkin bir biçimde dâhil olmasının nedenlerinden biri, fabrikanın ortaklarından olan Koç'un ya da Koç Grubunun Konfederasyon içindeki ağırlığıdır. ${ }^{23}$ Diğer bir neden ise henüz kuruluşunu yeni tamamlayan TISK'in kendisi ile birlikte işveren sendikalarının, gerekliliğini ve yararlığını işverenler nezdinde kanıtlama çabasıdır. Bununla birlikte TÍSK’in söz konusu çabası, başka bir ifadeyle Kavel grevine "gösterdiği hassasiyet ve aktivitenin" karşıllk bulduğu belirtilmelidir. Nitekim birçok işveren Kavel greviyle "teşkilatlanmak zaruretini idrak" etmiş ve "bu hadise işveren sendikalarına ve dolayısıyla Konfederasyona bir hayli üye kazandırmıștır" (Lök, 1966: 244). TİSK'in Kavel grevi ile özel olarak ilgilenmesinin son bir gerekçesi, grevin özelliklerinden kaynaklanmaktadır. TİSK Kavel grevinden önce, “gerek İstanbul'da, gerek Türkiye'nin muhtelif sanayi bölgelerinde, zaman zaman işverenlerle işçiler arasında iş uyuşmazlıkları" çıktığının görüldüğünü ve "hatta grev teşebbüslerine de rastlandığını" belirtmektedir. Ancak "genel olarak işverenler tarafindan işçilerin grev, işçiler tarafindan işverenlerin lokavt yaptıkları iddialarıyla gelişen bu uyuşmazlıklar; hakem veya hâkim yoluyla giderilmiş ve olaylara sahne olan fabrikalarda işler kısa bir süre sonra normale dönmüştür” (İşveren, Şubat 1963: 22). Bu bakımdan TİSK grevin daha 5. gününde Kavel grevine kadar Türkiye'de "biçbir işyerinde; ilgili kanun bükeümlerine uyularak birkaç işşinin işten çıkartıldiğ veya iş̧letmenin ü̈ret unsuruna girmeyen arzi bir ödeme olarak verdiği ynllhk ikeramiyelerin az, olduğu iddia edilerek, "oturma grevi" ado altında bes gün devam eden kanunsuz bir harekete rastlanmamıști" demektedir. TISK'e göre "üstelik 20. asırda, demokrasiyle idare edilen ve özel teşebbüse serbestçe iş yapma hakkının, mülkiyet hakkının Anayasa ile tanındığı

"hava da amma soğuk be, Allah yardımomı olsun. Fakirin ekmeği ile neden oynarlar bilmem ki. Haklarmizi verseler kiyamet mi kopar, sanki” demektedir (Baykal, 13 Şubat 1963: 6).

${ }^{22} \mathrm{Bu}$ sürece TISK ile birlikte MESS de dâhil olmuștur.

23 TISSK'In ilk yıllarındaki yönetim kurulu başkanı Şahap Kocatopçu, daha önce belirtildiği gibi, 1954-1980 arasında Koç grubuyla da ilgisi olan, Türkiye Şişe Cam Fabrikaları genel müdürüdür. Şişecam grubu İş Bankası bünyesinde yer almaktadır. Bu bakımdan İş BankasıŞişe Cam Grubu ithal ikameci birikim döneminde mevcut sanayi tesislerinin sermayelerine düzenli olarak iştirak etmiş, ayrıca başta Koç Holding olmak üzere sermaye gruplarıyla birçok ortaklık kurmuştur (Öztürk, 2011: 200). Bunun dışında metal sektöründe çok etkili olan Koç grubu MESS’in kuruluşunda öncü olması yanında, daha sonraki yıllarda da MESS'de etkinliğini sürdürmüştür. MESS ise TISSK'in kurucu üyelerindendir ve daha sonraki dönemde de TİSK'in yönetim kurulu üyeleri arasında niceliksel olarak ağır basan oranda yönetimde söz sahibi olmayı sürdürmüştür. 
Türkiye'de, bir işçi grubunun, ilgili kanunları ve bulunduğu yerde düzeni sağlamakla görevli polis kuvvetini hiçe sayarak bir işyerini kuşattığı; iyi niyetli insanları tehditle sindirerek çalışmalarına mani olduğu ve bütün bunlardan sonra ortaya çıkıp "sosyal adalet isteriz" diye haykırdığı görülmüş, duyulmuş şeylerden değildir" (İşveren, Şubat 1963: 22). Bu bakımdan TISK'in "elini uzatmaktan zevk ve bahtiyarlik duyduğu dost ve kardeș işçiler" tanımının dıșına çıkan Kavel işçileri, "bentlerini yıkıp, etrafa taşma tehlikesi gösteren" (Kip, Mart 1963: 6) bu kararlı ve örgütlü sosyal adalet arayışları ile TISSK'i kaygılandırmış görünmektedir.

Öte yandan TISK, Kavel grevini daha en baştan "kanunsuz grev" olarak ilan etmiş, grevin müsebbibini "tahrik edilmiş işçiler" olarak ortaya koymuş ve Kavel grevini, Türkiye'de "sosyal alanda, yeni bir düzene girmekte olunan" o günlerde "çalışma barışının kurulması için sarf edilen gayretlerin önüne çıkarılmak istenen engel" olarak nitelemiştir. ${ }^{24}$ Nitekim grevci isçcilerin grev nedeni olarak sunduğu unsurlar TİSK'e göre asılsızdır. TİSK'e göre, "her firsatta kendisinin de aslında bir işçi olduğunu söyleyen" yeni Müdür Üzümcü, "hem işverenin hem de işçilerin menfaat sağlaması için" "zarar eden fabrikaya bir çeki düzen vermek" amacındadır. $\mathrm{Bu}$ bakımdan Üzümcü önce, "emek unsurunun üstüne eğilmeyi gerekli bulmuş, prodüktivitenin artmasında huzur içinde çalışan sıhhatli ve bilgili işçilerin önemli rol oynayacağını düşünmüştür". Üzümcü’ye göre “ayrıca fabrikada çalışma disiplininin kurulması da şarttır" (İșveren, Subat 1963: 22-23).

TİSK böylece nedenlerini belirlediği Kavel grevinin, daha sonra gün gün analizini gerçekleştirmektedir. "Fabrika yetkilileri tarafindan tutulan zabitları" kullanan TISK, işçilerin oturma grevinin 28 Ocak günü, önce kablo kaplama dairesinde başladığını, daha sonra "diğer dairelere de sirayet ettiğini”" ve "fabrikanın bütün faaliyetlerinin durdurulduğunu” belirtmektedir (İşveren, Şubat 1963: 23). Sözü edilen zabıtlarda, fabrikanın tamamına yayılan bu hareketin, tek tek isimleri sayılan işçilerce, "muhtelif şekillerde tazyik, tehdit ve hakaret etmek suretiyle" diğer

24 TİSK'e göre Kavel grevi, hem usulsüz hem de kanunsuz bir grevdir. Bunun birinci nedeni, grev hakkının, Anayasa teminatı altında bulunduğunun iddia edilemeyeceğidir. Çünkü Anayasa'nın 47. maddesine göre "grevin tatbik taræı ile istisnalar kanunla düzenlenir. Bu kanunun isdar için de muayyen bir müddet tanınmıștır. Bu busustaki kanun benüz çıkarılmamıs olduğu gibi, bu müddet de henüz dolmamıştır'. Dolayısıyla TISK'e göre işçilerin grev hakk1 yoktur. İkinci neden ise grev hakkının işçiye tanınmış olduğu ve ilgili kanununun yürürlüğe girdiği kabul edilse bile, grevci işçilerin grev sebebi olarak ileri sürdüğü, ikramiye ve işten çıkarılma hususlarının kanuni bir grev nedeni olarak kabul edilememesidir. "Cünkü ikramiye, bir ücret

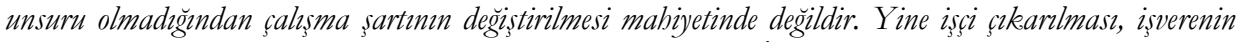
kanuni bir hakkeıdır ve grev sebebi olarak kullanılamaz". TISK bir an için, işverenin çalsşma şartlarına riayet etmemiş olduğunun kabul edilmesi durumunda dahi, grevin kanunsuz olduğunu ileri sürmektedir. "Zira grevlerin de bir takım șart ve usulleri bulunmaktader; isyerini terk mecburiyeti ile pike hareketlerine gitme ve tabrip hareketlerine bassurma yasağa da her yerde kabul edilmiş esaslardır. Ancak Kavel iş̧̧ileri bunlara uymamıștır’ (İşveren, Mart 1963b: 10). 
işçileri "greve iştirake zorlamasıyla" gerçekleştiği ileri sürülmektedir. Bunun üzerine işveren "kanunsuz hareketleri tespit edilen 10 işçinin işine, İş Kanunu'nun 16. maddesine uyarak son vermiştir" (İşveren, Şubat 1963: 23). Zabitlara göre grevin ikinci günü, işlerine son verilen işçiler eylemlerini fabrika önünde devam ettirmiștir. TISK ayrıca grevin ikinci gününde Bölge Çalışma Müdürlügü̈nden temsilcilerin "uzlaştırma gayretleri” neticesinde Kavel ișverenlerinin "iyi niyet göstergesi” olarak 10 işçiyi tekrar işe aldığını belirtmektedir. Ancak TİSK, "çalışacaklarını vaat ederek işyerine giren bu 10 işçinin kendileri çalışmadığı gibi diğer işçileri de gene çalışmamaya icbar ettiklerini” ileri sürmektedir. Bunun üzerine Kavel işvereni, söz konusu 10 işçinin işine yine aynı gün son vermiş, üstelik bu 10 işçinin yanına 3 işçi daha eklemiştir. Kavel işvereninin iyi niyeti bununla da sınırlı değildir. Nitekim grevin beşinci gününde, 13 işçiden sonra, bütün işçilerin işine son verilmiştir (İșveren, Şubat 1963: 23-24). Bütün işçilerin işine son verilmesi TíSK'e göre yerinde bir karardır, aksi durumda "fabrika bir suç yuvası haline sokulacaktır". 25 Zabıtlara göre işten çıkarılan işçiler, 2 Şubat'tan itibaren fabrika önünde kurdukları çadırlarla eylemlerine devam etmiştir. İşveren ise 31 Ocak'ta Sarryer Savcillı̆ına yaptığı ilk müracaat ile "fabrika dâhilinde ve haricinde gerekli emniyet tedbirlerini" almıştır. TISK ayrıca, "fabrikasını işletmek zorunda olan" Kavel işvereninin "çalışmak istemeyen işçilerinin yerine yeni işçiler almak" amacıyla "gazetelere yeni işçi alınacağına dair ilan verdiğini”" fakat "kapının önündeki işçi barikatı yüzünden, ne çalışmak isteyen büro personelinin ne de çalışmak için fabrika idaresine başvuracak olan yeni işçilerin içeriye girebildiğini" belirtmektedir. Bu durum karşısında işveren 7 Şubat'ta fabrikayı süresiz olarak kapatmışır (İşveren, Şubat 1963: 25).

TISKK bütün bu gelişmeler üzerine Kavel'deki 173 işçinin ikramiye ve işe iade taleplerini, "milli bir sorun" haline dönüştürerek, Cumhurbaşkanı'ndan siyasi parti liderlerine kadar herkesin konuyla ilgilenmesini talep ettiği bir telgraf göndermiştir. TISK bu telgrafta Kavel'de "tahrik edilen haksiz ve kanunsuz zor kullanma hareketlerinin" işverenin "bütün uzlaştırma gayretlerine ve idari ve adli mercilere başvurulmasına" rağmen devam ettiğini, "mal ve can kaybı tehlikesinin meydana geldiğini" belirtmektedir. TİSK telgrafta ayrıca, "bazı işçi sendikacıları" tarafindan grevin "kanunsuz ve haksız taleplerinin işverence kabul edilmesi için tazyik

25 Bütün işçilerin işine son verilmesi, işçilere göre, işverenin çalışma şartlarındaki değişikliği zorla kabul ettirmek maksadıyla uyguladığı lokavttır. Ancak TİSK'e göre, işverenin işçileri işten çıkarması lokavt olarak tanımlanamaz. Çünkü işveren çalışma şartlarını kendi lehine değiştirmek maksadıyla işi durdurmuş değildir. Ayrıca kanunun aradığı belirli yeter sayıda işçiyi işten çıkarmış değildir. Yine işveren işçiyi ilk safhada çıkarırken her birine ihbarını yapmış ve tazminat haklarını da ödemiştir. İkinci safhada da diğer işçileri çalışmaya davet etmiş ve fakat bunlar çalışmamakta direnince noter huzurunda her birine ihbarını yaparak iş akitlerini feshetmiştir (İşveren, Mart 1963b: 11). 
vasıtası" ve "toplu sözleşme grev ve lokavt kanun tasarısının meclislerden diledikleri gibi çıkmasını sağlayacak baskı hareketlerine bir basamak"26 olarak kullanıldığını belirtmekte ve bu bakımdan "dayanışma gösterisi halinde genişletilmeye çalsşlan bu kanunsuz hareketlerin acilen men’i ve faillerin cezalandırılmasını" istemektedir (İşveren, Şubat 1963: 26). Bununla birlikte TISSK'in hükümetten beklediği desteği bulduğu ayrıca belirtilmelidir. Nitekim greve polis 27 ve savcılık ${ }^{28}$ tarafindan yapılan müdahaleler dışında, dönemin Çalışma Bakanı Bülent Ecevit işvereni destekleyen açıklamalarda bulunmuştur. Tıpkı TİSK gibi, işçi sendikası liderlerinin "uygunsuz" tercihlerini vurgulayan Ecevit'e göre, "olayla ilgili bir kısım sendikacılar, hak iddialarını takip için kendilerine açık olan hukuki yolları seçecek ve Bakanlık'a başvuracak yerde, meseleyi Çalışma Bakanlığı'nın yetki sınırlarından çıkararak bir emniyet ve asayiş meselesi haline getirmiştir". Ecevit ayrıca, TÜRK-İS yöneticilerine de "işçilerin hak iddialarını takip için tutulan yolun uygunsuzluğunu ve tehlikelerini zamanında belirttiğini" ifade etmektedir. Ancak Ecevit bu uyarılara rağmen, "ilgili sendikacıların tuttukları yol yüzünden Kavel Fabrikası olayının hala sürüp gittiğini ve bunun acısının işveren kadar işçi tarafindan da çekildiğini”" ifade etmektedir (İşveren, Mart 1963a: 29). Ecevit'in bu açılamasının TÍSK’i oldukça memnun ettiği ayrıca belirtilmelidir. Nitekim Kocatopçu, Ecevit'in açıklamasını değerlendirdiği konuşmasında, Ecevit'in

${ }^{26}$ Kavel grevinin daha önce belirtildiği gibi, esas nedenleri işten çıkarılan işçiler ve ödenmeyen ikramiyelerdir. Bunun dışında doğrudan, 275 sayılı Kanun’un düzenlenmesini hızlandırmak gibi amaç taşımamaktadır. Ancak Aydın’ın belirttiği üzere (2010: 141-142) Maden-İşs Sendikası doğrudan grev hakkını kazanmak için Kavel grevini uygulamış olmasa bile Türkiye işçi sınıfına grev hakkını armağan etme gibi bir amacı gözettiği söylenebilir. Nitekim Maden-İş bu dönemde Anayasa'da yer almasina rağmen uzun bir süredir düzenlenmeyen grev kanununun bir an evvel çıkarılmasını istemektedir.

${ }^{27} 13$ Şubat Çarşamba günü yani, grevin on yedinci gününde, Kavel işçileri ile polis arasında ilk çatışma yaşanmıştır. Basında yer alan bilgilere göre, polis müdahalesi fabrikaya girmek isteyen büro memurlarının işçilerce içeri sokulmak istememesi nedeniyle gerçekleşmiştir. Polislerin işçilere "komünistler" diye bağırarak müdahale ettiği olayda polis ve işçiler arasında yaralananlar olmuştur, ancak sonuçta polisler, memur otomobilini, zor kullanarak fabrikaya sokabilmiştir(İşveren, Mart 1963a: 24-26).

28 İşveren polisin greve müdahalesinin ertesi gününde yani 14 Şubat'ta İçişleri Bakanı’nı bir telgrafla bilgilendirirken, "vilayete ve savciliğa" yeniden başvurmuştur. Bu başvurulurda polisin greve müdahalesine de yer verilmekte ve "kanunsuz grevin" devam ettiği belirtilmektedir. İşverenin bu başvuruları karşılık bulmuş ve 15 Şubat’ta Sarıyer Savcıllı̆̆1, "3 gün önce Kavel Fabrikası önünde olan çatışma ile ilgili bir kovuşturma açmıştır" (İşveren, Mart 1963a: 26-28). Sarıyer Savcılı̆̆ının açtuğı bu soruşturma, 18 Şubat'ta sonuçlandırılmış ve ilgili mahkeme "üç işçinin tevkif edilmelerine karar vermiştir". Bu işçiden ikisi cezaevine gönderilirken, biri hakkında "g1yabi tevkif müzekkeresi kesilmiştir” (İşveren, Mart 1963a: 33). 
açılamasının kendilerini "huzura sevkettiğini" ve "büyük bir teminat" verdiğini belirtmektedir (İsveren, Mart 1963a: 30).

Öte yandan Kavel grevi, grevin 34. gününde Başbakan Yardımcısı ve Devlet Bakanı Turhan Feyzioğlu ile Çalışma Bakanı Ecevit’in, işveren ve işçi temsilcileri ile gerçekleştirdiği uzun bir toplantının ardından, taraflar arasında imzalanan protokol ile sonlandırılmıştır. Söz konusu protokolde, "işçilere ödenmeyen ikramiyelerin ödeneceği", işten ilk çıarıllan " 4 işçinin yeniden işe alınmasının işverenden istenmeyeceği" ancak "bu işçilere işveren tarafindan tazminat ödeneceği" ve işlerine daha sonra son verilen diğer " 9 işçinin fabrikanın çalışmaya başlamasından itibaren 20 gün içinde fabrikaya alınmaları" karara bağlanmıştır (İşveren, Mart 1963a: 39-41). ${ }^{29}$ TISKK ise "basite irca edilmiş şekliyle bir somunu paylaşma ihtilafi" olan Kavel grevinin bu şekilde "barışla son ermesini" "şükranla" anmaktadır. TISK'e göre bu "ihtilafın sağduyulu tarafları, bazı müfritlerin fiili hareket teşebbüslerine set çekmenin en iyi niyetli gayretlerini, barışçı müzakerelerin faziletine inanmış insanlar olarak, kaba sokak mücadelelerinden seviyeli bir masa münazarasına intikal ettirmekle en mükemmel ve insan haysiyetine en yakışır şekilde göstermişlerdir" (Altınelli, Mart 1963: 5). Bu bakımdan TİSK'e göre Kavel grevinin tarihi önemi "sakat zihniyetlerin" "hüsran ve mağlubiyetinde" yatmaktadır. Nitekim "şuursuz ve kontrolsüz bir hareket halinde memleket sathına yayılma istidadında" olan "Kavel ihtilafı, çalışma hayatında kader birliği yapmış insanlara 35 buhranlı gün yaşattıktan sonra", "memlekette bir yandan sermaye düşmanlığı, diğer yandan emek istismarı temalarını işleyerek iki tarafin arasını açıcı emellere set çekmek bakımından kötü niyetli tahrikçilerin, bulanık suda balık avlamak isteyen firsatçıların hüsran ve mağlubiyeti; öte yandan karşılıklı güven ve sevgi içinde huzur ve istikrarlı bir istihsal faaliyeti ile memleketin iktisadi kalkınma çabasına katılma şuurunu benimsemiş sağduyuluların kesin zaferi ile sonuçlanmıştır” (Kip, Mart 1963: 6).

\section{Sonuç}

TISSK'in kuruluş yılları Türkiye çalışma ilişkileri tarihinin önemli dönüm noktalarından birini teşkil etmektedir. Bu yıllarda çalışma ilişkilerinin temel kurumları olan sendika, toplu pazarlık, grev-lokavt ilk defa bir arada ve karşılıklı

${ }^{29}$ Grevin sonlanmasının ardından 12 işçi tutuklanmıştır. 52 Kavel işçisiyle ilgili olarak açılan dava sayısı da 5’i bulmuştur. Bu işçilere, Toplantı ve Gösteri Yürüyüşleri Kanunu'na muhalefet, polise fiili mukavemet, mesken masuniyetini ihlal v.b. suçlamalar yöneltilmiştir. 10 Haziran'da, tutuklu 6 işçinin serbest birakılmalarından sonra işten atılmaları üzerine, fabrikanın kaplama dairesinde çalışan 30 kadar işçi yeniden, toplu halde iş bırakmıştır. Bu eylem nedeniyle duruma el koyan sıkıyönetim 6 işçiyi gözaltına almıştır (TSA 2, 1998: 240). 
iliş̧kileri içerisinde düzenlemeye kavuşturulmuştur. $\mathrm{Bu}$ yeni düzenlemeler, işverenlerin "sendika" biçiminde hızla örgütlenmesini ve işveren sendikalarının üst düzeyde temsilini sağlayacak olan TíSK'in kurulmasını da etkileyen temel unsurlardandır. Bu yıllar aynı zamanda dünya konjonktürü, işçi sınıfının nicel ve nitel yükselişi ve ithal ikameci ekonomi politikaları gibi unsurların etkisiyle Türkiye'de siyasal özgürlük ve çoğulculuk ortamında neo-korporatist eğilimlerin ortaya çıktığı yıllardır. Bu bakımdan TİSK de kuruluş yıllarında "sosyal ortaklık" fikrini esas alan neo-korporatist eğilim paralelinde söylem geliştirmiş ve benimsediği İsveç işveren örgütlenmesinin "sosyal adalet" prensibini her firsatta dile getirmiştir.

Bununla birlikte söz konusu grev hakkı olunca TISK daha ihtiyatlı bir söylem tercih ederken, uygulamada sosyal adalet prensibi ile bağdaşmayan bir tutum sergilemektedir. Nitekim grev hakkını "idam cezas1" (Kip, Mart 1963: 6-7) metaforuyla açıklayan TİSK, Kavel grevi incelemesinde görüldüğü gibi, Kavel işçilerinin sosyal adalet talebi karşısında oldukça sert, uzlaşmaz bir tutum takınmışır. Bir yandan "hukuk nizamını korumakla görevli olan Devletin" bu görevini işçilere karşı icra etmesi için çaba harcamış, bir yandan "işçilerin makul isteklerini" karşılamamak için işverene işçilerin işine son vermesi, işine son verilen işçilerin yerine yeni işçi alması, fabrikayı tamamen kapatması gibi yol ve yöntemler sunmuş ve diğer yandan da grevi bölmeye, işçilerin direncini kırmaya yönelik taktikler geliştirmiştir. TISKK Kavel grevini, "Konfederasyon politikasının değişmez yönünü gösteren" ve "geçmişte olduğu kadar gelecekteki tutumuna da 1şık tutan" "umumi prensipler" temelinde ele aldığını belirtmektedir (Altınelli, Mart 1963: 4). TİSK'in kuruluş yıllarında son derece güçlü bir sınıf bilincine sahip olduğunu gösteren bu prensipler, çalışma yaşamında "tarafsız hakem" niteliği vurgulanan hükümet tarafindan da desteklenmiştir. Bütün bunlar Türkiye'de çalışma ilişkileri bakımından TíSK'in kuruluş yıllarında ilk adımları atılan yeni dönemin evrileceği yönü işaret ederken, TİSK'in "sosyal adalet prensibine ve bunu koruyan hükümlerin müeyyidesi olan" grev hakkına esasen nasıl yaklaştığını da göstermiş olmaktadir. 


\section{KAYNAKÇA:}

Altıntelli, M. (Mart 1963) "İşçi-İşveren Münasebetleri ve Konfederasyonumuzun Tutumu”, İssveren, Cilt:1, Sayı: 6, 4-5.

Aydın, Z. (2010) "Kanunsuz” Bir Grevin Öyküsü, Kavel 1963, İstanbul: Sosyal Tarih Yayinları.

Balc1, Ş. G. (1998) "Lokavt”, Türkiye Sendikac1lk Ansiklopedisi Cilt: 2, İstanbul: Kültür Bakanlığı ve Tarih Vakfi Ortak Yayını.

Baydur, R. (2008) Türk Sendikacılığı İşçi-İşveren, Ankara: Sinemis Yayınları.

Baykal, S. (13 Şubat 1963) "Kavel Önünde Bir Gece”, Yön, Yıl: 2, Sayı: 61, 6.

Çelik, A. (2010) Vesayetten Siyasete Türkiye'de Sendikacilık (1946-1967), İstanbul: İletişim Yayınları.

Çelik, A. (2014) Avrupa Birliği Sosyal Politikası ve Türkiye, İstanbul: Kitap Yayınevi.

Çelik, A. (2021) "Saraçhane'den 15-16 Haziran'a İşçi Sınıfının Müstesna Yılları: Altmışlı Yıllar”, Kaynar, M. (der.) Türkiye'nin 1960’lı Yılları içinde, İstanbul: İletişim Yayınlar1, 633-667.

Çoker, F. Çakmak, V. Asena, E. Alan, E. Bayman, Z. Gürsel. S. (Tarihsiz) "Cumhuriyet Meclislerinin Anatomisi", "Cumhuriyet Meclislerinin Üye Listeleri”, Cumhuriyet Dönemi Türkiye Ansiklopedisi, 10. Cilt, İletişim Yayınları.

Esin, P. (1974) Türkiye'de İşveren Sendikacıllğı, Ankara: Ankara Üniversitesi Siyasal Bilgiler Fakültesi Yayınları No: 373.

İbrahimoğlu, R. (1974) “İşveren Sendikalarının Doğuşu ve Gelişmesi”, Sosyal Siyaset Konferanslar1 Dergisi, Say1: 25, 115-130.

İşveren. (Ekim 1962) "İşverenler Bir An Önce Teşkilatlanmalıdırlar”, Sayı: 1, Cilt: 1, 14-16.

İşveren. (Kasım 1962) “İstanbul İşveren Sendikaları Birliği”, Cilt:1, Sayı: 2, 14-23.

İşveren. (Ocak 1963) “Türkiye İşveren Sendikaları Konfederasyonu”, Cilt: 1, Sayı: 4, 14-21.

İşveren. (Ocak 1963a) “Toplu Sözleşmede Tehlikeli İki Husus”, Cilt 1, Sayı: 4, 22-24. İssveren. (Şubat 1963) "Kavel Fabrikasındaki Olay”, Cilt: 1, Sayı: 5, 22-26.

İşveren. (Mart 1963) “Türkiye Maden-İşs Sendikasının Yayınladığ1 Bildiriler ve Ötesi”, Cilt: 1, Say1: 6, 15-18.

İşveren. (Mart 1963a) “Otuz Beş Günün Hikâyesi”, Cilt: 1, Sayı: 6, 19-28.

İşveren. (Mart 1963b) "Son Anlaşmadan Evvel Yapılan Toplantılardaki Görüşmelerin Tahlilil”, Cilt:1, Sayı: 6, 9-11.

İşveren. (Temmuz 1963) “Toplu Sözleşme Grev ve Lokavt Kanunu ile Sendikalar Kanunu Nihayet Çıktı”, Cilt: 1, Sayı: 10, 19-21.

İşveren. (Temmuz 1963a) "Sayın İşverenler”, Cilt:1, Sayı: 10, 3.

Kip, H. (Ekim 1962) "İşveren-Işşi Münasebetlerinde Sendikaların Rolü”, İşveren, Cilt: 1, Sayı: 1, 10-11. 
Kip, H. (Mart 1963) 'Kavel Protokolünün Tahlili", İşveren, Cilt: 1, Sayı: 6, 6-8.

Kocatopçu, Ş. (Kasım 1962) "Hürriyet İçinde Kalkınma”, İşveren, Cilt:1, Sayı: 2, 6-8.

Koç, Y. (1980) Türkiye’de İşveren Örgütleri.

Koray, M. Topçuoğlu, A. (1994) Sosyal Politika, İzmir: Ezgi Kitabevi Yayınları.

Koray, M. (2005) Avrupa Toplum Modeli, Ankara: İmge Kitabevi.

Koray, M. Çelik, A. (2007) Avrupa Birliği ve Türkiye'de Sosyal Diyalog, Ankara: Belediye-İş Yayınları.

Lök, İ. (1966) "Türkiye'de İşveren Teşekkülleri”, Sosyal Siyaset Konferansları Dergisi, Sayı: 17, 238-249.

Makal, A. (1999) Türkiye'de Çok Partili Dönemde Çalşma İlişkileri: 1920-1946, Ankara: İmge Kitabevi.

Makal, A. (2015) Ameleden İşçiye Erken Cumhuriyet Dönemi Emek Tarihi Çalışmaları, İstanbul: İletişim Yayınları.

MESS. (1999) Gelenek ve Gelecek 1. Cilt, MESS Yayın No: 315, İstanbul: BZD Yayıncilik.

Öztürk, Ö. (2011) Türkiye'de Büyük Sermaye Grupları Finans Kapitalin Oluşumu ve Gelişimi, İstanbul: Sav Yayınları.

Saymen, F. H. (Aralık 1962) "Sendikalar Kanunu Tasarısı Hakkında Mütalaa", İşveren, Cilt 1, Sayı: 3, 9-14.

TOBB. (1962) Toplu İş Sözleşmesi, Grev ve Lokavt Kanun Tasarısı Hakkında Görüșümüz, Ankara: TOBB Matbaası.

Türkiye Sendikacıllk Ansiklopedisi. (1998) "Kavel Direnişi, 1963" Cilt: 2, İstanbul: Kültür Bakanlığı ve Tarih Vakfı Ortak Yayını.

Yön. (6 Şubat 1963) "Koçta Grev", Yıl: 2, Sayı: 60, 6.

Yön. (13 Şubat 1963) “Türk İşçisinin Tarihi Mücadelesi”, Yı1: 2, Say1: 61, 5-6.

Yücekök, A. N. (1972) Türkiye'de Dernek Gelişimleri (1946-1968), Ankara Üniversitesi Siyasal Bilgiler Fakültesi Yayınları No: 335, Ankara: Sevinç Matbaasi. 